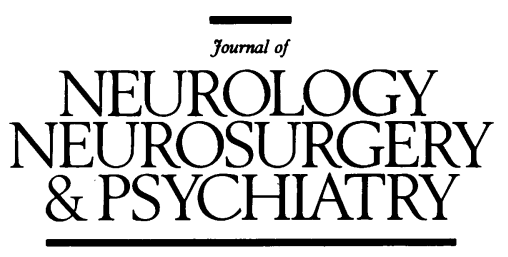

\title{
Archie Cochrane's challenge: can periodically updated reviews of all randomised controlled trials relevant to neurology and neurosurgery be produced?
}

\author{
C E Counsell, H Fraser, P A G Sandercock
}

\begin{abstract}
Archie Cochrane's challenge
Archie Cochrane (1909-88), a respiratory epidemiologist and clinical trialist, recognised early in his career the major dilemma facing the National Health Service (NHS)-namely, how can the service fulfil its aim to provide free, comprehensive, and effective care which is equally accessible to all with only finite resources? Cochrane argued that, given the financial limitations, only those forms of care that research had clearly shown to be beneficial should be offered by the NHS. In particular, he emphasised that the randomised, controlled trial was the form of research most likely to determine whether or not a particular treatment was effective. ${ }^{1}$ His message was that forms of care which have been shown to do more good than harm should be encouraged, whereas those that do more harm than good should be discarded, and the many forms of care which have unknown effects should be provided, as far as possible, only in the context of a trial.
\end{abstract}

The number of trial reports that appear each year is now so large, however, that it is very difficult for any one individual to find and synthesise information from all the relevant studies relating to a given treatment. To cope with this "information overload", most people rely on personal knowledge of a few key trials or on reviews of primary research in journals or textbooks. Unfortunately, the quality of most medical reviews leaves much to be desired because many reviewers do not approach the task of assembling, analysing, and reporting the results of a review with the same care they take with their own original research. Many reviews, because they are unsystematic and do not use a formal statistical method to derive a "best estimate" of treatment effect from all the information available, tend to reach conclusions that are, at best, biased, and at worst, frankly wrong. ${ }^{23}$ Archie Cochrane himself identified this problem more than a decade ago: "It is surely a great criticism of our profession that we have not organised a critical summary, by specialty or subspecialty, adapted periodically, of all relevant randomized controlled trials."

\author{
What is a systematic review and what are the \\ benefits?
}

There are two main components to a systematic review (also called an overview or meta-analysis): a systematic search for all relevant randomised trials (whether published or unpublished); and the use of an appropriate statistical method to derive a "best estimate" of treatment effect in that particular collection of trials-that is, one which uses all the available information. There are a large number of trials evaluating different treatments to manage and prevent stroke (tables 1 and 2) and many trials in other fields of neurology and neurosurgery (tables 2 and 3). There are over 400 apparently randomised trials of antiplatelet treatment alone. Among these are over 200 truly randomised studies whose results have been reviewed recently. ${ }^{16-18}$ It is well beyond the resources of a single physician to undertake a systematic review of such a large body of evidence, yet a systematic review is the only means of deriving a useful summary of the evidence. Although the number of trials in other areas of neurology and neurosurgery is perhaps not so daunting, it is safe to assume that most clinical neurologists and neurosurgeons would welcome systematic reviews of all the available evidence from trials, particularly if the review were regularly updated in the light of any new evidence. Such reviews would also be of considerable interest not only to clinicians, but also to purchasers and providers of health care, insurance companies, scientists planning future research and, most importantly, patients.

\section{Hazards of conventional (unsystematic) reviews} EVIDENCE FROM OTHER AREAS

It is not enough just to undertake a clinical trial. It is also important to review each new trial in the context of previous similar studies; failure to do so-namely, to perform systematic reviews of all trials, has harmed many patients. Antman et $a l^{3}$ showed that, if the evidence from trials of thrombolysis in acute myocardial infarction had been 
Table 1 Stroke Review Group of the Cochrane Collaboration: planned reviews

\begin{tabular}{|c|c|c|}
\hline Intervention & Reviewer and country & $\begin{array}{l}\text { Approximate no. of } \\
\text { RCTs to be reviewed }\end{array}$ \\
\hline \multicolumn{3}{|l|}{ Acute stroke (medical treatment): } \\
\hline $\begin{array}{l}\text { Antiplatelet agents } \\
\text { Anticoagulants }\end{array}$ & $\begin{array}{l}\text { P Sandercock, UK and the Antiplatelet Trialists Collaboration } \\
\text { P Sandercock, UK }\end{array}$ & $\begin{array}{r}5 \\
30\end{array}$ \\
\hline Fibrinolytic therapy & J Wardlaw, UK & 30 \\
\hline Haemodilution & K Asplund, Sweden & 20 \\
\hline $\begin{array}{l}\text { Glycerol therapy } \\
\text { Calcium antagonists }\end{array}$ & $\begin{array}{l}\text { G Boysen, Denmark } \\
\text { J-M Orgogozo, France }\end{array}$ & 15 \\
\hline & M Limburg, The Netherlands & 30 \\
\hline Corticosteroids & N Qizilbash, UK & 20 \\
\hline \multirow{2}{*}{\multicolumn{3}{|c|}{$\begin{array}{l}\text { Acute stroke (rehabilitation): } \\
\text { Physiotherapy }\end{array}$}} \\
\hline & & \\
\hline $\begin{array}{l}\text { Speech therapy } \\
\text { Cognitive rehabilitation }\end{array}$ & P Enderby, UK & 20 \\
\hline & $\begin{array}{l}\text { N Lincoln, UK } \\
\text { A House, UK }\end{array}$ & $\begin{array}{r}10 \\
5\end{array}$ \\
\hline Stroke units & M Dennis/P Langhorne, UK & 10 \\
\hline \multicolumn{3}{|l|}{ Acute stroke (prevention of venous thromboembolism'): } \\
\hline $\begin{array}{l}\text { Graded compression stockings } \\
\text { Antiplatelet agents }\end{array}$ & T Lensing, The Netherlands & 40 \\
\hline \multirow{2}{*}{\multicolumn{3}{|c|}{$\begin{array}{l}\text { Acute treatment and prevention of subarachnoid and primary } \\
\text { intracerebral haemorrhage: }\end{array}$}} \\
\hline & & \\
\hline Medical therapies $\}$ & $\int \mathrm{J}$ van Gijn/G Rinkel & \\
\hline Surgical therapies $\}$ & $\left\{\begin{array}{l}\text { A Algra/D Hasan } \\
\text { M Vermeulen, The Netherlands }\end{array}\right.$ & 30 \\
\hline \multicolumn{3}{|l|}{ Treatment of cerebral venous sinus thrombosis: } \\
\hline Anticoagulants & J Stam, The Netherlands & 2 \\
\hline \multicolumn{3}{|l|}{ Stroke prevention: } \\
\hline $\begin{array}{l}\text { Antiplatelet agents and anticoagulants for atrial fibrillation } \\
\text { Antiplatelet agents in other high risk groups }\end{array}$ & A Laupacis, Canada & 10 \\
\hline $\begin{array}{l}\text { Antrplatelet agents in other high risk groups } \\
\text { Carotid endarterectomy }\end{array}$ & P Sandercock, UK and the Antiplatelet Trialists Collaboration & $>200$ \\
\hline - & CP Warlow, UK & 10 \\
\hline
\end{tabular}

RCT $=$ randomised, controlled trial.

* These trials were performed almost exclusively in patients with conditions other than acute stroke: their results are, however, of relevance to thromboprophylaxis in patients with stroke.

reviewed systematically as it accumulated, then proof beyond reasonable doubt of its effectiveness would have been established by the late 1970s (about 10 years before the results from the Gruppo Italiano per lo Studio della Streptochinasi nell' Infarto Miocardico (GISSI-1), the first of the trials that was large enough on its own to confirm the effectiveness of thrombolysis) ${ }^{3}$ If the results of such a systematic review in the late 1970s had been widely adopted in medical practice at that time, many thousands of premature deaths from acute myocardial infarction would have been avoided over the next 20 years. In their recommendations about which forms of treatment were effective in myocardial infarction, textbooks and review articles sometimes lagged up to 10 years behind the evidence available from systematic reviews-for example, although a systematic review had shown that the routine use of either lignocaine or calcium antagonists following acute myocardial infarction was not clearly effective, and (in the case of prophylactic lignocaine) indeed probably increased mortality, review articles and textbooks continued to recommend their routine use. ${ }^{3}$

Yet another example exists in the field of obstetrics. For some time there has been uncertainty about whether or not a short course of corticosteroids given to women expected to give birth prematurely reduced the risk of morbidity and mortality in the baby. The first randomised trial of corticosteroids was performed in 1972 and several more trials followed, some showing statistically significant benefit, others not, but none was large enough on its own to provide overwhelming evidence of benefit. If a systematic review of these trials had been performed in 1982, it would have strongly indicated that steroids were of clinically (and statistically) significant benefit. ${ }^{39}$ Unfortunately, such a review was not done until 1989 , by which time a further seven trials had been reported. The result showed that steroids reduced the odds of babies dying from the complications of prematurity by about a third to a half. ${ }^{39}$ Thus, had the results of all the available research evidence been assembled, properly reviewed, and then widely disseminated 10 years earlier, thousands of infant deaths (and disability in thousands more babies who survived) might have been avoided.

EVIDENCE FROM NEUROLOGY AND NEUROSURGERY In some fields, there have been a number of small trials, each of which has been unconvincing, but a systematic review has revealed clear evidence of benefit: recent systematic reviews have provided clear evidence that stroke units reduce mortality, ${ }^{11}$ compression stockings clearly prevent venous thromboembolism ${ }^{37}$ and steroids given to children with meningitis reduce the incidence of complications such as deafness. ${ }^{33}$ It is hard to quantitate the harm that has been done to patients by our failure to detect the benefits from these treatments, but it is potentially large. In fields where there is relatively little evidence from randomised trials, such as the efficacy of antibiotic prophylaxis in relatively clean neurosurgical procedures, unsystematic reviews of the evidence have reached opposite conclusions: one reviewer favouring routine use, ${ }^{40}$ and the other not. ${ }^{41}$ Sometimes, clinicians continue to use a treatment despite evidence from randomised trials and a well conducted, systematic review showing no clear evidence of benefit. Haemodilution therapy for acute ischaemic stroke has not been shown to be effective, ${ }^{7}$ but it is still widely used in many parts of Europe (International Stroke Trial Collaborative Group, personal communication). Presumably, the clinicians who use haemodilution have, on the basis of their own unsystematic review of selected parts of the medical literature, reached an over-optimistic conclusion about its benefits.

\section{Systematic reviews are not a panacea}

Systematic reviews have their limitations. The usefulness of a review will depend on the number of trials available, the quality of the trials included and the overall methodological quality of the review process itself. ${ }^{14164243}$ There is also the problem of publication bias-the selective reporting of statistically significant results and suppres- 
Table 2 Published systematic reviews (or meta-analyses) relevant to neurology and neurosurgery, comparing treatment with control *

\begin{tabular}{|c|c|c|c|}
\hline Intervention & No. of trials & Year published & Conclusion $†$ \\
\hline $\begin{array}{l}\text { Treatment of acute stroke: } \\
\text { Calcium antagonists } \\
\text { Calcium antagonists }^{6} \\
\text { Haemodilution }^{7} \\
\text { Glycerol }^{8} \\
\text { Heparin }^{9} \\
\text { Thrombolytic therapy }^{10} \\
\text { Admit to stroke unit }{ }^{11} \\
\text { Rehabilitation }^{12}\end{array}$ & $\begin{array}{r}5 \\
12 \\
12 \\
7 \\
15 \\
6 \\
10 \\
36\end{array}$ & $\begin{array}{l}1990 \\
\text { In press } \\
1991 \\
1992 \\
1993 \\
1992 \\
1993 \\
1993\end{array}$ & $\begin{array}{l}\text { No } \\
\text { No } \\
\text { No } \\
\text { No } \\
\text { No } \\
\text { No } \\
\text { Yes } \\
\text { No }\end{array}$ \\
\hline 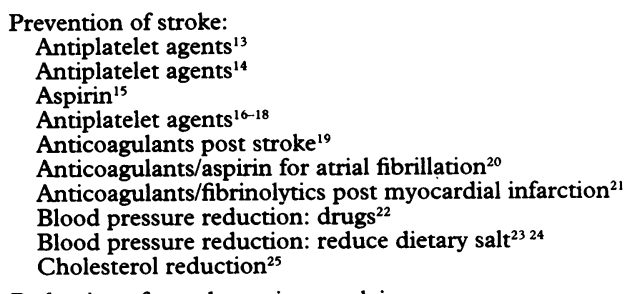 & $\begin{array}{r}7 \\
31 \\
7 \\
174 \\
16 \\
5 \\
9 \\
14 \\
10 \\
13\end{array}$ & $\begin{array}{l}1988 \\
1988 \\
1991 \\
1994 \\
1988 \\
1993 \\
1992 \\
1990 \\
1991 \\
1993\end{array}$ & $\begin{array}{l}\text { No } \\
\text { Yes } \\
\text { No } \\
\text { Yes } \\
\text { No } \\
\text { Yes } \\
\text { Yes } \\
\text { Yes } \\
\text { Yes } \\
\text { No }\end{array}$ \\
\hline $\begin{array}{l}\text { Reduction of post-herpetic neuralgia: } \\
\text { Acyclovirire } \\
\text { Acyclovirit }^{27} \\
\text { Steroids }^{26} \\
\text { Steroids }^{28}\end{array}$ & $\begin{array}{r}7 \\
14 \\
5 \\
4\end{array}$ & $\begin{array}{l}1989 \\
1991 \\
1989 \\
1990\end{array}$ & $\begin{array}{l}\text { No } \\
\text { Yes } \\
\text { No } \\
\text { Yes }\end{array}$ \\
\hline $\begin{array}{l}\text { Back pain: } \\
\text { Spinal manipulation }{ }^{29}\end{array}$ & 23 & 1992 & Yes \\
\hline $\begin{array}{l}\text { Multiple sclerosis: prevention of relapse: } \\
\text { Linoleic acid } \\
\text { Azathoprine }^{31}\end{array}$ & $\begin{array}{l}3 \\
4\end{array}$ & $\begin{array}{l}1984 \\
1991\end{array}$ & $\begin{array}{l}\text { No } \\
\text { No }\end{array}$ \\
\hline $\begin{array}{l}\text { Epilepsy: } \\
\text { Lamotrigine }{ }^{32}\end{array}$ & 4 & 1991 & Yes \\
\hline 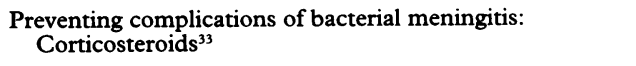 & 4 & 1993 & Yes \\
\hline $\begin{array}{l}\text { Migraine prophylaxis: } \\
\text { Propranolol }^{34} \\
\text { Biofeedback }^{34}\end{array}$ & $\begin{array}{l}25 \\
35\end{array}$ & $\begin{array}{l}1990 \\
1990\end{array}$ & $\begin{array}{l}\text { Yes } \\
\text { Yes }\end{array}$ \\
\hline $\begin{array}{l}\text { Prevention of pulmonary embolism in medical and surgical } \\
\text { Unfractionated heparin } \\
\text { Low molecular weight heparin } \\
\text { Compression stockings } \\
\text { Antiplatelet drugs }{ }^{38}\end{array}$ & $\begin{array}{l}70 \\
52 \\
12 \\
80\end{array}$ & $\begin{array}{l}1988 \\
1992 \\
1994 \\
1994\end{array}$ & $\begin{array}{l}\text { Yes } \\
\text { Yes } \\
\text { Yes } \\
\text { Yes }\end{array}$ \\
\hline $\begin{array}{l}\text { Prevention of ischaemic deficit after subarachnoid haemorr } \\
\text { Calcium antagonists } \\
\text { Calcium antagonists }^{6}\end{array}$ & $\begin{array}{l}6 \\
7\end{array}$ & $\begin{array}{l}1990 \\
\text { In press }\end{array}$ & $\begin{array}{l}\text { Yes } \\
\text { Yes }\end{array}$ \\
\hline
\end{tabular}

* Systematic review was defined as a study that described the methods used to identify trials from as many different sources as possible and then used an

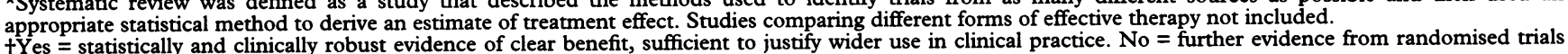
+ Yes $=$ statistically and clinically robust evidence of clear
required before any major change in practice is indicated.

†The trials were, in general, not conducted in neurological or neurosurgical patients, but the results are of relevance to neurology and neurosurgery.

sion (mainly by authors, but sometimes by journal editors) of statistically non-significant results-which remains difficult to overcome. ${ }^{1416}$

Systematic reviews are not a substitute for large scale, well conducted trials: on the contrary, such reviews may help to determine research priorities and guide the design of trials needed to provide a definitive answer to a particular question.

\section{The Cochrane Collaboration}

Efforts to provide continuously updated systematic reviews have varied enormously in different medical spe- cialties. Two, however,-obstetrics and neonatologyhave shown the way forward. Enthusiasts, inspired by Archie Cochrane, attempted to identify all possible trials in these fields, and to produce a series of systematic reviews based on them. Over 3000 trials were assembled and about 500 systematic reviews were prepared. These reviews have been published as books, ${ }^{44} 45$ and on computer disk ${ }^{46}$ and are regularly updated.

In 1992, the NHS Research and Development Programme established the United Kingdom Cochrane Centre in Oxford, under the directorship of Dr Iain Chalmers, to facilitate and coordinate systematic reviews of treatments in other specialties. The aim is to prepare,

Table 3 Interventions for which a large number of randomised clinical trials have been undertaken, and where a systematic review would be helpful to guide clinical practice and future research

\begin{tabular}{|c|c|c|c|}
\hline Disease & Intervention* & Number of trials identified by Medline & Estimated no. of trials $\ddagger$ \\
\hline $\begin{array}{l}\text { Migraine } \\
\text { Parkinson's disease } \\
\text { Epilepsy } \\
\text { Brain tumour } \\
\text { Meningitis } \S\end{array}$ & $\begin{array}{l}\text { Prophylactic drugs } \\
\text { Anti-parkinsonian drugs } \\
\text { Anticonvulsants } \\
\text { Radiotherapy, chemotherapy, surgery } \\
\text { Antibiotics }\end{array}$ & $\begin{array}{r}201 \\
163 \\
115 \\
88 \\
83\end{array}$ & $\begin{array}{l}480 \\
390 \\
280 \\
210 \\
200\end{array}$ \\
\hline
\end{tabular}

* Includes comparison with control or with other effective therapy, considered as "standard".

tEstimate derived by Medline searching from 1966-93. Such searches are generally estimated to detect only half of all published randomised trials.

fVery approximate estimate obtained by doubling the number found by Medline and adding $20 \%$ to allow for unpublished but completed studies. This method tVery approximate esto to treat malignant brain tumours included 176 protocols of trials that were active after $1985^{52}$ (not all of which were published) thus the estimate of 210 is probably unduly low.

SIncludes prevention of postoperative infections in neurosurgical patients. 
maintain, and disseminate systematic reviews of randomised trials of the effects of health care. Within a year of the launch of the centre, an international Cochrane Collaboration has evolved, with further centres in Scandanavia, Canada, and the United States, and more planned in Italy and Australia. Using the model of the Pregnancy and Childbirth Group, these reviews will be prepared by a number of small groups, each registered with the Cochrane Collaboration. Each group will consist of a few people working together in an area of common interest under the supervision of an editorial board. Such groups may wish to cover certain diseases, ${ }^{47} 48$ certain types of treatment-or whole specialties. ${ }^{445}$ The Cochrane Collaboration will provide essential organisational support to reduce the work for individual reviewers and to avoid duplication of effort. An international register of trials is being developed which will assist reviewers in the enormous task of identifying all the relevant trials to be included in a particular review. The coordinating group have established guidelines and protocols to ensure that all reviews are produced to a uniformly high standard.

Finally, the Cochrane Centres will help to ensure that the results of each review are sufficiently widely disseminated to influence decision making, both in clinical practice and in research. There has been some resistance among United Kingdom obstetricians to incorporate the evidence from the systematic reviews prepared by the Pregnancy and Childbirth Group into routine clinical practice and in the teaching of undergraduates and of obstetricians in training. ${ }^{49}$ There will no doubt be similar barriers to dissemination of information among neurologists and neurosurgeons, so the Cochrane Collaboration will make major efforts to ensure that the evidence from reviews is diffused as widely as possible. Reviews will be published electronically which will allow them to be easily updated in the light of new evidence or of any valid criticisms. Reviewers will also be encouraged to publish their results "in parallel" in journals or books, to maximise the spread of information.

THE STROKE COLLABORATIVE REVIEW GROUP

Over the past few years several systematic reviews have been published in the field of stroke (table 2). It is, therefore, perhaps not surprising that a Stroke Review Group was one of the first to formally register with the Cochrane Collaboration last year. Over the next few years the Stroke Review Group plans to extend the existing work to produce reviews of randomised trials dealing with prevention, treatment, and rehabilitation of ischaemic and haemorrhagic stroke (including subarachnoid haemorrhage). At present, there are about 20 reviewers from six countries, covering interventions as diverse as carotid endarterectomy for stroke prevention to speech therapy for aphasia after stroke (table 1). The identification of all relevant randomised trials has been helped enormously by the existence of a register-the Ottawa Stroke Trials Registry. ${ }^{50}$

\section{Other relevant systematic reviews}

Much more needs to be done within neurology and neurosurgery (outside cerebrovascular disease). Using a Medline search and personal knowledge, we have so far identified 35 systematic reviews relevant to neurology and neurosurgery (table 2). Many of these need to be updated. There is a need, however, for reviews in many other areas. Table 3 shows further interventions where many randomised trials have already been done but there is an urgent need for a comprehensive and systematic review. This list is necessarily incomplete, but gives some indication of the scale of the problem.

\section{CONCLUSION: NEUROLOGY AND NEUROSURGERY COULD}

RISE TO THE CHALLENGE

In the era when patients are well informed, managers seek cost-effective treatments, clinicians struggle to keep up with the burgeoning medical literature and there is an increasing trend for malpractice claims against illinformed doctors, there is a clear need for up to date, systematic reviews of the effectiveness of treatment. Review groups within the Cochrane Collaboration offer an ideal opportunity to prepare such reviews. The Stroke Review Group is a multidisciplinary group, but other Cochrane Review groups within neurology and neurosurgery could relate to just one discipline.

The work of a review group is reduced if there is an up to date register of all randomised trials (planned, current and completed) in that particular field. Such registers already exist for trials in neurosurgery and the treatment of brain tumours and could be valuable resources for review groups covering these topics. ${ }^{51} 52$

It is to be hoped that neurologists and neurosurgeons will rise to Archie Cochrane's challenge: with the evidence from systematic reviews, the care of patients with neurological and neurosurgical conditions could be more rational, more effective and less harmful.

C E COUNSELL H FRASER P A G SANDERCOCK Department of Clinical Neurosciences, Western General Hospital, Edinburgh EH4 $2 X U$,

Correspondence to: Dr P A G Sandercock

Dr C E Counsell is supported by a Wellcome Research Training Fellowship. H Fraser is supported by the Chief Scientist Office, Scottish Office Home and Health Department.

1 Cochrane AL. Effectiveness and efficiency. Random reflections on health services. London: Nuffield Provincial Hospitals Trust, 1972.

Mulrow CD. The medical review article: state of the science. Ann Intern Med 1987;106:485-8.

3 Antman EM, Lau J, Kupelnick B, Mosteller F, Chalmers TC. A comparison of results of meta-analyses of randomized control trials and recommendations of clinical experts. $\mathscr{f} A M A 1992 ; 268: 240-8$.

4 Cochrane AL. 1931-1971: a critical review with particular reference to the medical profession. In: Medicines for the year 2000. London: Office of Health Economics, 1979:1-11.

5 Gelmers HJ, Hennerici M. Effect of nimodipine on acute stroke. Pooled results from five randomized trials. Stroke 1990;21 (Suppl. IV):81-4.

6 Di Mascio R, Marchioli R, Tognoni G. From pharmacological promises to controlled clinical trials to meta-analysis and back: the case of nimodipine in controled chersials to meta-analysis and back: the case of analysis (in press)

7 Asplund K. Hemodilution in acute stroke. Cerebrovasc Dis 1991;1(Suppl. 1):129-38.

8 Roygvi-Hansen B, Boysen G. Intravenous glycerol treatment of acute stroke-a statistical overview. Cerebrovasc Dis 1992;2:1 1-3.

9 Sandercock PAG, van den Belt AGM, Lindley RI, Slattery J Antithrombotic therapy in acute ischaemic stroke: an overview of the completed randomised trials. F Neurol Neurosurg Psychiatry 1993 56:17-25.

10 Wardlaw JM, Warlow CP. Thrombolysis in acute ischaemic stroke-does it work? Stroke 1992;23:1826-39.

11 Langhorne P, Williams BO, Gilchrist W, Howie K. Do stroke units save lives? Lancet 1993:342:395-8.

12 Ottenbacher KJ, Jannell S. The results of clinical trials in stroke rehabilitation research. Arch Neurol 1993;50:37-44.

13 Sze PC, Reitman D, Pincus MM, Sacks HS, Chalmers TC. Antiplatelet agents in the secondary prevention of stroke: meta-analysis of the ranagents in the secondary prevention of stroke: met
domized controlled trials. Stroke 1988;19:436-42.

14 Antiplatelet Trialists' Collaboration. Secondary prevention of vascular disease by prolonged antiplatelet treatment. $B M \Im 71988 ; 296: 320-31$.

15 Stachenko SJ, Bravo G, Cote R, Boucher J, Battista RN. Aspirin in transient ischemic attacks and minor stroke: a meta-analysis. Fam Pract Res
sache 7 1991;11:179-91.

16 Antiplatelet Trialists' Collaboration. Collaborative overview of randomised trials of antiplatelet treatment. Part I: Prevention of death, myocardial infarction and stroke by prolonged antiplatelet therapy in various categories of patients. $B M F$ 1994;308:81-106.

17 Antiplatelet Trialists' Collaboration. Collaborative overview of ran- 
domised trials of antiplatelet treatment. Part II: Maintenance of vascular graft or arterial patency by antiplatelet therapy. $B M \mathcal{F} 1994 ; 308$ : 159-68.

18 Antiplatelet Trialists' Collaboration. Collaborative overview of randomised trials of antiplatelet treatment. Part III: Reduction in venous thrombosis and pulmonary embolism by antiplatelet prophylaxis amon surgical and medical patients. BMF 1994;308:235-46.

19 Jonas S. Anticoagulant therapy in cerebrovascular disease: review and meta-analysis. Stroke 1988;19:1043-8.

20 Boysen $G$ and the Atrial Fibrillation Investigators. Risk factors for stroke and the effect of warfarin in non-valvular atrial fibrillation: a pooling of and the effect of warfarin in non-valvular atrial fibrillation:
data from clinical trials. Neurology 1993;43(Suppl. A):390.

21 Vaitkus PT, Berlin JA, Schwartz S, Barnathan ES. Stroke complicating acute myocardial infarction. A meta-analysis of risk modification by anticoagulant and thrombolytic therapy. Arch Intern Med 1992;152: $2020-4$

22 Collins R, Peto R, MacMahon S, et al. Blood pressure, stroke, and coronary heart disease. Part 2, short-term reductions in blood pressure: an overview of randomized drug trials in their epidemiological context. Lancet 1990;335:827-38.

23 Law MR, Frost CD, Wald NJ. Analysis of data from trials of salt reduction. BMF 1991;302:819-24.

24 Law MR, Frost CD, Wald NJ. Dietary salt and blood pressure. $\mathcal{f}$ Hypertension 1991;9(Suppl. 6):537-41.

25 Atkins D. Cholesterol reduction and the risk for stroke in men. A metaanalysis of randomised controlled trials. Ann Intern Med 1993;119: 136-45.

26 Schmader KE, Studenski S. Are current therapies useful for prevention of postherpetic neuralgia? A critical analysis of the literature. $₹$ Gen Intern Med 1989;4:83-9.

27 Crooks RJ, Jones DA, Fiddian AP. Zoster associated chronic pain: an overview of clinical trials with acyclovir. Scand $f$ Infect Dis 1991;80(Suppl.):62-8.

28 Lycka BAS. Postherpetic neuralgia and systemic corticosteroid therapy Efficacy and safety. Int ₹ Dermatol 1990;29:523-7.

29 Anderson R, Meeker WC, Wirick BE, Mootz RD, Kirk DH, Adams A. A meta-analysis of clinical trials of spinal manipulation. $\mathcal{f}$ Manipulative Physiol Ther 1992;15:181-94.

30 Dworkin RH, Bates D, Millar JHD, Paty DW. Linoleic acid and multiple sclerosis: a reanalysis of three double blind trials. Neurology 1984; 34:1441-5.

31 Yudkin PL, Ellison GW, Ghezzi A, et al. Overview of azathioprine treatment in multiple sclerosis. Lancet 1991;338:1051-5.

32 Richens A, Yuen AW. Overview of the clinical efficacy of lamotrigine. Epilepsia 1991;32(Suppl. 2):13-6.

33 Schad UB, Lips U, Gnehm HE, Blumberg A, Heinzer I, Wedgwood J, Swiss Meningitis Study. Dexamethasone therapy for bacterial meningitis in children. Lancet 1993;342:457-61

34 Holroyd KA, Penzien DB. Pharmacological versus non-pharmacological prophylaxis of recurrent migraine headache: a meta-analytic review of clinical trials. Pain 1990;42:1-13.

35 Collins R, Scrimgeour A, Yusuf S, Peto R. Reduction in fatal pulmonary embolism and venous thrombosis by perioperative administration of subcutaneous heparin. Overview of results of randomised trials in general, orthopedic and urologic surgery. $N$ Engl $f$ Med 1988;318: 1162-73.

36 Leizorovicz A, Haugh MMC, Chapuis FR, Samama MM, Boissel JP. Low molecular weight heparin in prevention of perioperative thrombosis. BMF 1992;305:913-20.

37 Wells PS, Lensing AWA, Hirsh J.. Graduated compression stockings in the prevention of postoperative venous thromboembolism: a metathe prevention of postoperative venous
analysis. Arch Intern Med 1994;154:67-72.

38 Tettenborn D, Dycka J. Prevention and treatment of delayed ischaemic dysfunction in patients with aneurysmal subarachnoid haemorrhage. Stroke 1990;21 (Suppl. IV):85-9.

39 Crowley P. Corticosteroids prior to preterm delivery. In: Enkin MW, Keirse MJNC, Renfrew MJ, Neilson JP, eds. Pregnancy and childbirth module [Cochrane database of systematic reviews, Review No. 02955, 26 April 1993] Oxford: Cochrane Updates on Disk, Update Software, 1993.

40 Shapiro $M$. Prophylaxis in otolaryngologic surgery and neurosurgery: a critical review. Rev Infect Dis 1991;13(Suppl. 10):858-68.

41 Brown EM. Antimicrobial prophylaxis in neurosurgery. If Antimicrob Chemother 1993;31(Suppl. B):49-63.

42 Oxman $\mathrm{AD}$, Guyatt $\mathrm{GH}$. Guidelines for reading literature reviews. Can Med Assoc ₹ 1988;138:697-703.

43 Sacks HS, Berrier J, Reitman D, Ancona-Berk VA, Chalmers TC. Metaanalyses of randomized controlled trials. $N$ Engl f Med 1987;316:450-5.

44 Chalmers I, Enkin M, Keirse MJNC, eds. Effective care in pregnancy. Oxford: Oxford University Press, 1989.

45 Sinclair JC, Bracken MB, eds. Effective care of the newborn infant. Oxford: Oxford University Press, 1992.

46 Enkin MW, Keirse MJNC, Renfrew MJ, Neilson JP, eds. Pregnancy and childbirth module [Cochrane database of systematic reviews]. Oxford: Cochrane Updates on Disk, Update Software, 1993.

47 Early Breast Cancer Trialists' Collaborative Group. Systemic treatment of early breast cancer by hormonal, cytotoxic, or immune therapy. Lancet 1992;339:1-15.

48 Advanced Ovarian Cancer Trialists' Group. Chemotherapy in advanced ovarian cancer: an overview of randomised clinical trials. $B M \mathcal{F}$ 1991;303:884-93.

49 Paterson-Brown S, Wyatt JC, Fisk NM. Are clinicians interested in up to date reviews of effective care? BMF 1993;307:1464

50 Moher D and the Ottawa Stroke Trials Registry Collaborative Group. The development of the Ottawa Stroke Trials Register. Controlled Clinical Trials (in press)

51 Easterbrook PJ. Directory of registries of clinical trials. Statistics Med 1992;11:345-423.

52 Kelly PJ. Investigative protocols to treat malignant brain tumours in North America. Neurosurgery 1989;24:459-72.

\section{NEUROLOGICAL STAMP}

\section{René Théophile Hyacinthe Laënnec (1781-1826)}

The great advance in clinical medicine in the 19th century was the art of diagnosis. René Laënnec, pupil of both Bichat and Corvisart, advanced the work of Leopold Auebrugger, the inventor of percussion. Auebrugger learned from boyhood experiences in his father's inn that thumping barrels gave different sounds depending on the liquid content. Later he applied this to patients' chests. Laënnec, in his childhood, had watched children listening to the sounds of taps on a hollow log. It was this observation that lead to the invention of the stethoscope and auscultation. In 1816 Laënnec was consulted by a young woman with a cardiac condition. Her age and sex inhibited examination by the usual method of placing an ear on the breast-instead, he placed his ear over one end of a tightly rolled sheet of paper, the other end of which he put over the heart. To his surprise, the heartbeat could be heard more clearly than by the direct method; later a hollow, wooden tube was used. With this device and his sensitive musician's ear (he played the flute), Laënnec described audible pulmonary and cardiac lesions and confirmed these with numerous autopsies. The stethoscope, in improved flexible versions, was a major advance in physical diagnosis and rapidly became a standard part of every doctor's equipment.

Laënnec was appointed to the Chair of Medicine at the College of France at the age of 41 and in the next year succeeded Corvisart as a full professor. Like his other teacher, Bichat, he was a regimental surgeon in the Revolution and an early victim of pulmonary tuberculosis. The publication of his Traité de l'ausculation medité in 1819 , and an enlarged second edition in 1823 , placed Laënnec among the great clinicians. His name in medical terminology is not attached to his great achievement in physical diagnosis, but to the hobnail liver and soft casts expectorated in bronchial asthma. This French postage stamp was issued in 1952 (Stanley Gibbons 1157, Scott 685).

L F HAAS

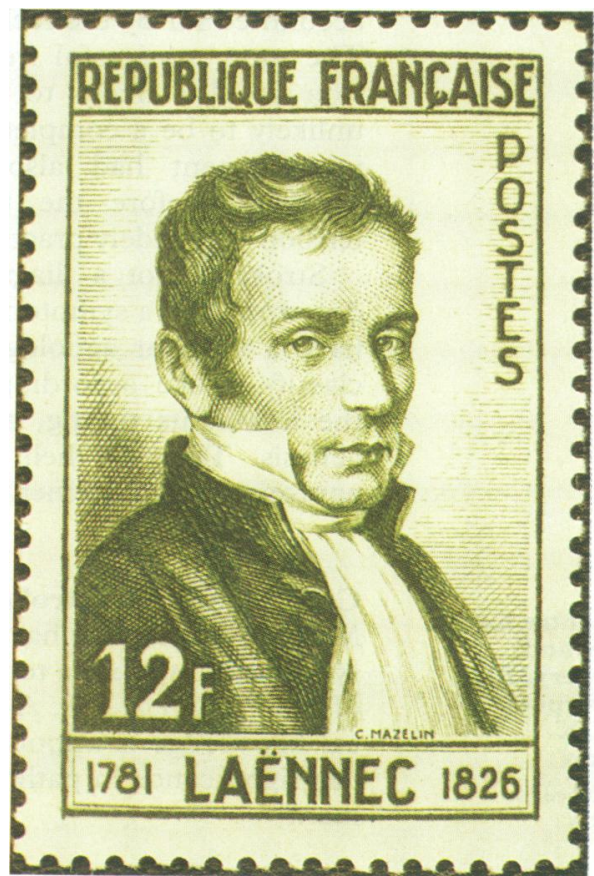

